\title{
REVIEW ON SHOT PEENING OF NON FERROUS ALLOY
}

\begin{abstract}
V. Pavithran
Department of Mech Eng

Coimbatore Coimbatore

Abstract -Shot peening is a surface level important process for improving the mechanical properties of ferrous and non-ferrous. In this paper presents a review on process parameters and mechanical properties of Non-ferrous metals. Non-ferrous metals is result increasing use in automotive parts such as axles helical gears, fillets transmission shafts etc. Effect of shot peening on mechanical properties is studied to collect data from several papers. Form the paper reviewed, shot peening improves the mechanical properties of nonferrous alloy.
\end{abstract}

Sri Eshwar College of Engineering, Sri Eshwar College of Engineering,

\author{
U.Magarajan \\ M.Y.Industries \\ Chennai
}

Keywords - shotpeening, tensile, fatigue, impact, hardness.

\section{INTRODUCTION}

Shot peening is the cold working process which are used to increase the residual stress of the component. In shot peening, large no. of small metallic balls were forced to strike the surface of the component ti high velocity. When the metallic ball shitting the surface, some impact energy is created in the surface. Due to this,there will be a plastic deformation occurs on the surface which tends to change the residual stress of the material. This causes the change in mechanical properties of the materials. Shot peening process is shown in Figure 1.

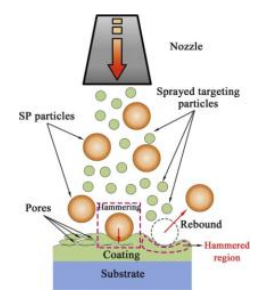

Fig.1.shot peening process

\section{LITERATURE SURVEY}

Juan Gonzalez et.al (2017) et al. have investigated Al 6063 alloy under different shot peening treatments. They found that SSP shot peening process improves the fatigue behaviour more than $15 \%$ compared to all other processes. Vaibhav Pandey et.al (2017) has studied causes of USSP on corrosion properties of $\mathrm{Al} 7075$. They concluded that there is an enhance in the surface roughness and residual stress with an enhance in shot peening timing. It lowers the corrosion resistance and promotes increase other properties such as nanostructure, low plastic deformation, less micro-strain. Kovaciet al. (2018) studied the effect of shot peening of low-alloy steel for different process parameters. The plastic deformation, surface roughness, residual stress increases with increase in intensities of shot peening and maximum values obtained at 24A. It also improves the corrosion resistance of the material. Barry et al. (2008) studied the fatigue behaviour of cast A8 magnesium alloy. Their study shows that there is an improves in fatigue strength up to 5 times, depending on the applied stress and $30 \%$ increase the endurance limit of the material. Ruidong et al. have investigated the corrosion behaviour of the FSW joint of 7075 aluminium alloy after shot peening treatment. This study reveals that it improves the corrosion resistance on the welded surface due to shot peening treatment. Liu et al. (2017) has investigated the fatigue performance of shotpeened Ti-6Al-4V alloy under surface polishing treatment. They concluded that fatigue life gradually increases with an increase in shot peening intensity. Sara Bagherifard et al. (2017) studied the effect of severe shot peening on the properties of AZ31 magnesium alloy. SSP increases surface roughness up to $150 \%$, microhardness up to $133 \%$, and surface wettability up to $20 \%$. In this study, concluded shot peening was found to decrease corrosion resistance the samples. Omar Hatamlehet al.(2007) have studied the residual stress in FSW of 7075-T7351 aluminium under the laser and shot peening. They concluded that laser shot peening results in a significant decrease in the tensile residual stress at the surface of the specimen. Ruixia Zhang et al. (2016)Have investigated the mechanical properties of AZ31B magnesium alloy before and after LSP. Their result concluded that large improvement in the properties such as hardness increases from 57 $\mathrm{HV}$ to $69 \mathrm{HV}$ and yield strength from $128 \mathrm{MPa}$ to 


\section{International Journal of Engineering Applied Sciences and Technology, 2019 \\ Vol. 4, Issue 2, ISSN No. 2455-2143, Pages 135-140 \\ Published Online June 2019 in IJEAST (http://www.ijeast.com)}

152 MPa.Meo et al. (2016) has analysed the residual stress under shot peening by finite element analysis. They concluded that the capability of shot peening decreased tensile residual stress produced by welding and increase the fatigue life of the welded joints. Sano et al. (2012) has investigated the fatigue life of FSW of A6061-T6 aluminium under laser peening without coating. For unwelded specimen, the fatigue strength improves from $110 \mathrm{MPa}$ to $170 \mathrm{MPa}$ at $10^{7}$ cycles. For welded specimen, it increases from $90 \mathrm{MPa}$ to $120 \mathrm{MPa}$. The fatigue life is higher than the un-welded specimen as compared with laser peened FSW specimen. Chuan Xu et al. (2017) have investigated mechanical properties of $\mathrm{Mg} / \mathrm{Ti}$ weldments under high-energy shot peening. The high- energy shot peening had increased tensile strength to $24.5 \%$ as compared with the un-peened specimen. Vielma et al. (2014) has investigated the fatigue life of quenched and tempered medium-carbon alloy steel under different shot peening intensities. Their studied shows that all treatments produce increment in fatigue life as compared with the untreated specimen. The highest values obtained at $10 \mathrm{~A}$ which produce $45 \%$ to $50 \%$ of tensile strength under alternating loads. Zheng Xuan et al. (2017) has studied about surface roughness of Al2024 alloy under shot peening process by using the Finite Element Method. They concluded that the initial stage of shot peening increases surface roughness rapidly and becomes slow when the coverage reaches $100 \%$. Fouad et al. (2011) has studied wear properties of AZ31 magnesium samples and compare shot peened specimen with untreated samples. There is no change when the pressure is low and at high pressure, wear rate decreased as compared. Fouad et al. (2011) has investigated about fatigue behaviour of AZ31 magnesium alloy under surface treatment (EP \& BB) by conducting rotating beam and bending fatigue test. Their result shows that the fatigue life of $\mathrm{BB}$ samples was higher than the EP samples. Cancan Liu et al. (2018) has investigated the corrosion behaviour of AZ31 bending strength of cylindrical pipe of AZ31 magnesium alloy. In this study, a tensile, compressive and bending test conducted. Their result shows that there is a significant improvement in the properties. Ying-Kang Wei et al. (2017) has investigated the corrosion behaviour of nickel coating AZ31B Magnesium alloy which undergoes in- situ shot peening. They concluded that the shot peened samples exhibit good corrosion resistance than the untreated samples. Table 1 shows the summarize results of various shot peening process.

\section{CONCLUSION}

The conclusion has been made through the review of different papers which as follows, Shot peening processes extensively improves fatigue life of the material based on the shot intensity and and to the surface polishing treatments. This wills helpto increase corrosion resistance and there by the rate of corrosion will decreases. It improves the surface hardness with the increase in shot intensity and surface coverage. Italsoimpliesanimprovementin otherpropertiessuch astensile strength,wearrate, surface wettability etc depending upon the treatment.

Table 1 Summary of shot peening results of non ferrous metals from various papers

\begin{tabular}{|c|c|c|c|}
\hline References & Material & Process & Result \\
\hline $\begin{array}{l}\text { Juan Gonzalez } \\
(2017)\end{array}$ & Al6063 alloy & Shot peening & Shot peening improvesfatigue up to $15 \%$. \\
\hline $\begin{array}{l}\text { Vaibhav Pandey } \\
\text { (2017) }\end{array}$ & Al7075 alloy & $\begin{array}{l}\text { Ultrasonic } \\
\text { shot peening }\end{array}$ & $\begin{array}{l}\text { It increases surface properties } \\
\text { withincrease in shot peening timing. }\end{array}$ \\
\hline Barry (2008) & A8 Mg alloy & Shot peening & $\begin{array}{l}\text { The fatigue strength increases up to five } \\
\text { times based on applied stress and } 30 \% \text { in } \\
\text { endurance limit. }\end{array}$ \\
\hline Z.G Liu (2017) & $\begin{array}{l}\text { Ti-6Al-4V } \\
\text { alloy }\end{array}$ & $\begin{array}{l}\text { Shot peening \& } \\
\text { Surface polishing } \\
\text { treatment }\end{array}$ & $\begin{array}{l}\text { The fatigue life increases with the } \\
\text { increase in shot intensity. }\end{array}$ \\
\hline
\end{tabular}


International Journal of Engineering Applied Sciences and Technology, 2019

Vol. 4, Issue 2, ISSN No. 2455-2143, Pages 135-140

Published Online June 2019 in IJEAST (http://www.ijeast.com)

\begin{tabular}{|c|c|c|c|}
\hline $\begin{array}{l}\text { Sara Bagherifard } \\
\text { (2017) }\end{array}$ & AZ31B Mg alloy & $\begin{array}{l}\text { Severe shot } \\
\text { peening }\end{array}$ & $\begin{array}{l}\text { This process increases surface } \\
\text { roughness, micro hardness, and surface } \\
\text { wettability of the material. }\end{array}$ \\
\hline $\begin{array}{l}\text { Omar Hatamleh } \\
(2007)\end{array}$ & $\begin{array}{l}7075-\mathrm{T} 7351 \\
\text { Aluminium } \\
\text { alloy }\end{array}$ & $\begin{array}{l}\text { Laser and } \\
\text { conventional shot } \\
\text { peening }\end{array}$ & $\begin{array}{l}\text { Both process decreases the tensile } \\
\text { residual stress }\end{array}$ \\
\hline Ruixia Zhang (2017) & $\begin{array}{l}\text { AZ31B } \quad \mathrm{Mg} \\
\text { alloy }\end{array}$ & $\begin{array}{l}\text { Laser shot } \\
\text { peening }\end{array}$ & $\begin{array}{l}\text { This process implies } \\
\text { improvement in hardness and yicant } \\
\text { strength. }\end{array}$ \\
\hline Meo (2003) & Weldments & Shot peening & $\begin{array}{l}\text { This process decreases the tensile } \\
\text { residual stress and it improves fatigue } \\
\text { strength. }\end{array}$ \\
\hline Sano (2012) & $\begin{array}{l}\text { A6061-T6 } \\
\text { Aluminium } \\
\text { alloy }\end{array}$ & $\begin{array}{l}\text { FSW \& laser } \\
\text { shot peening }\end{array}$ & $\begin{array}{l}\text { Shot peening improves the fatigue life of } \\
\text { treated specimen than the untreated } \\
\text { specimen. }\end{array}$ \\
\hline Chuan Xu (2017) & $\begin{array}{l}\mathrm{Mg} / \mathrm{Ti} \\
\text { weldments }\end{array}$ & $\begin{array}{l}\text { High energy } \\
\text { shot peening }\end{array}$ & $\begin{array}{l}\text { It increases tensile strength to } 24.5 \% \text { as } \\
\text { compared with untreated samples. }\end{array}$ \\
\hline $\begin{array}{l}\text { Omar Hatamleh } \\
(2007)\end{array}$ & $\begin{array}{l}\text { 7075-T7351 } \\
\text { Aluminium } \\
\text { alloy }\end{array}$ & $\begin{array}{l}\text { Laser and } \\
\text { conventional } \\
\text { shot peening }\end{array}$ & $\begin{array}{l}\text { Both process decreases the tensile } \\
\text { residual stress. }\end{array}$ \\
\hline Ruixia Zhang (2016) & $\begin{array}{l}\text { AZ31B } \quad \mathrm{Mg} \\
\text { alloy }\end{array}$ & $\begin{array}{l}\text { Laser shot } \\
\text { peening }\end{array}$ & $\begin{array}{l}\text { This process implies } \\
\text { improvement in hardness and yicant } \\
\text { strength. }\end{array}$ \\
\hline Meo (2003) & Weldments & Shot peening & $\begin{array}{l}\text { This process decreases the tensile } \\
\text { residual stress and it improves fatigue } \\
\text { strength. }\end{array}$ \\
\hline Sano (2012) & $\begin{array}{l}\text { A6061-T6 } \\
\text { Aluminium } \\
\text { alloy }\end{array}$ & $\begin{array}{l}\text { FSW \& laser } \\
\text { shot peening }\end{array}$ & $\begin{array}{l}\text { Shot peening improves the fatigue life of } \\
\text { treated specimen than the untreated } \\
\text { specimen. }\end{array}$ \\
\hline Vielma (2014) & $\begin{array}{l}\text { Carbon alloy } \\
\text { steel. }\end{array}$ & Shot peening & $\begin{array}{l}\text { This process increases the fatigue and } \\
\text { tensile strength of max. } 45 \% \text { to } 50 \% \text {. }\end{array}$ \\
\hline Zheng Xuan (2017) & Al2024 alloy & Shot peening & $\begin{array}{l}\text { Surface roughness improves rapidly at } \\
\text { initial stage and increases slowly when } \\
\text { full coverage of the surface. }\end{array}$ \\
\hline Daoxia $\mathrm{Wu}(2017)$ & Ti1023 alloy & $\begin{array}{l}\text { Shot peened by } \\
\text { cast steel } \\
\& \text { ceramic shots. }\end{array}$ & $\begin{array}{l}\text { Cast steel shot produce high roughness } \\
\text { and plastic deformation than ceramic } \\
\text { shots. }\end{array}$ \\
\hline
\end{tabular}


International Journal of Engineering Applied Sciences and Technology, 2019

Vol. 4, Issue 2, ISSN No. 2455-2143, Pages 135-140

Published Online June 2019 in IJEAST (http://www.ijeast.com)

\begin{tabular}{llll}
\hline $\begin{array}{l}\text { Izumi } \\
\text { Fukuda (2013) }\end{array}$ & $\begin{array}{l}\text { AZ31B Mg } \\
\text { alloy }\end{array}$ & Shot peening & $\begin{array}{l}\text { Shot peening improves the properties } \\
\text { significantly. } \\
\text { Fouad (2011) }\end{array}$ \\
$\begin{array}{l}\text { AZ31B Mg } \\
\text { alloy }\end{array}$ & Shot peening & $\begin{array}{l}\text { Wear rate was decreased at high shot } \\
\text { peening intensity. }\end{array}$ \\
\hline $\begin{array}{l}\text { Ying-Kang } \\
\text { Wei (2017) }\end{array}$ & $\begin{array}{l}\text { AZ31B Mg } \\
\text { alloy }\end{array}$ & Shot peening & It provides good corrosion resistence. \\
\hline
\end{tabular}

\section{REFERENCES}

1. González, Juan, Sara Bagherifard, Mario Guagliano, and Ines Fernández Pariente. 2017. "Influence of Different Shot Peening Treatments on Surface State and Fatigue Behaviour of Al 6063 Alloy." Engineering Fracture Mechanics. 1-29

2. Pandey, Vaibhav et al. 2017. "Influence of Ultrasonic Shot Peening on Corrosion behavior of 7075 Aluminum alloy." Journal of Alloys and Compounds.

3. Hainsworth, S V, M E Fitzpatrick, S V Hainsworth, and M E Fitzpatrick. 2008. "Us Cr T." Effect of Shot Peening on the Fatigue Behaviour of Cast Magnesium A8." Materials Science \& Engineering A (2008).

4. Wong, Z G Liu T I, and W Huang N Sridhar. 2017. "Effect of Surface Polishing Treatment on the Fatigue Performance of Shot-Peened Ti - 6Al 4V Alloy." Acta MetallurgicaSinica (English Letters) 30(7): 630-40.

5. Bagherifard, Sara et al. 2017. "Effects of Nanofeatures Induced by Severe Shot Peening (SSP) on Mechanical, Corrosion and Cytocompatibility Properties of Magnesium Alloy AZ31." Acta Biomaterialia.

6. Hatamleh, Omar, Scott Forth, and Anthony P Reynolds. 2010. "Fatigue Crack Growth of Peened Friction StirWelded 7075 Aluminum Alloy under Different Load Ratios." 19(February): 99106.

7. Liu, Yang et al. 2018. "PT." Surface \& Coatings Technology (2017).

8. Ren, Zhencheng et al. 2017. "Effects Of Laser Shock Peening On The Wear And Degradation." : 1-6.

9. Meo, M, and R Vignjevic. 2003. "Finite Element Analysis of Residual Stress Induced by Shot Peening Process." 34: 569-75.
10. Sano, Y, K Masaki, T Gushi, and T Sano. 2012. "Improvement in Fatigue Performance of Friction Stir Welded A6061-T6 Aluminum Alloy by Laser Peening without Coating." Materials and Design .

11. Xu, Chuan et al. 2017. "Microstructure and Mechanical Properties of HighEnergy Shot-Peened Mg / Ti Weldments." 1718(May).

12. Hatamleh, Omar, Preet M Singh, and Hamid Garmestani. 2009. "Stress Corrosion Cracking Behavior of Peened Friction Stir Welded 2195 Aluminum Alloy Joints." 18(June): 406-13.

13. Hatamleh, Omar, Preet M Singh, and Hamid Garmestani. 2009. "Corrosion Susceptibility of Peened Friction Stir Welded 7075 Aluminum Alloy Joints." Corrosion Science 51(1): 135-43.

14. Vielma, A T, V Llaneza, and $F$ Belzunce. 2014. "Shot Peening Intensity Optimization to Increase the Fatigue Life of a Quenched and Tempered Structural Steel." Procedia Engineering 74: 273-78.

15. Xuan, Zheng, and Gao Dongwei. 2017. "Al2024 Alloy." 748: 229-34.

16. Yao, Changfeng et al. 2016. "Surface Integrity and Fatigue Analysis of ShotPeening for 7055 Aluminum Alloy under Different High-Speed Milling Conditions." 8(10): 1-10.

17. Bagherifard, Sara et al. 2017. "Effects of Nanofeatures Induced by Severe Shot Peening (SSP) on Mechanical, Corrosion and Cytocompatibility Properties of Magnesium Alloy AZ31." Acta Biomaterialia.

18. Luo, Ying-kang Wei Xiao-tao, and Chengxin Li Chang-jiu Li. 2016. "Optimization of In-Situ Shot-Peening-Assisted Cold Spraying Parameters for Full Corrosion Protection of Mg Alloy by Fully Dense Al-Based Alloy Coating." Journal of Thermal Spray Technology. 


\section{International Journal of Engineering Applied Sciences and Technology, 2019 \\ Vol. 4, Issue 2, ISSN No. 2455-2143, Pages 135-140 \\ Published Online June 2019 in IJEAST (http://www.ijeast.com)}

19. Kumar, R. S., Alexis, J., \&Thangarasu, V. S. (2017). Optimization of high speed CNC end milling process of BSL 168 Aluminium composite for aeronautical applications. Transactions of the Canadian Society for Mechanical Engineering, 41(4), 609-625

20. Kumar, S. R., Alexis, J. S., \&Thangarasu, V. S. (2017). Experimental Investigation of Influential Parameters in High Speed Machining of AMS 4205. Asian Journal of Research in Social Sciences and Humanities, 7(2), 508-523.

21. Ganeshkumar, S., Thirunavukkarasu, V., Sureshkumar, R., Venkatesh, S., \& Ramakrishnan, T. Investigation Of Wear Behaviour Of Silicon Carbide Tool Inserts And Titanium Nitride Coated Tool Inserts In Machining Of En8 Steel.

22. Kumar, S., Alexis, J., \&Thangarasu, V. S. (2016). Prediction of machining parameters for A91060 in end milling. Advances in Natural and Applied Sciences, 10(6 SE), 157-164

23. Kumar, R. S., Thangarasu, V. S., \& Alexis, S. J. (2016). Adaptive control systems in CNC machining processes--a review. Advances in Natural and Applied Sciences, 10(6 SE), 120-130.

24. Ramakrishnan, T., \&PavayeeSubramani, S. (2018). Investigation of PhysicoMechanical and Moisture Absorption Characteristics of Raw and Alkali Treated New Agave Angustifolia Marginata (AAM) Fiber. Materials Science, 24(1), 53-58. [SCI \& Scopus IF: $0.593]$

25. Ramakrishnan, T., \& Sampath, P. S. (2017). Dry Sliding Wear Characteristics of New Short Agave Angustifolia Marginata (AAM) Fiber-Reinforced Polymer Matrix Composite Material. Journal of Biobased Materials and Bioenergy, 11(5), 391-399.

26. Jeyakumar, R., Sampath, P. S., Ramamoorthi, R., \& Ramakrishnan, T. (2017). Structural, morphological and mechanical behaviour of glass fibre reinforced epoxy nanoclay composites. The International Journal of Advanced Manufacturing Technology, 93(1-4), 527535. Ramakrishnan, T., \& Sampath, P. S. (2017). Experimental investigation of mechanical properties of untreated new Agave Angustifolia Marginatafiber reinforced epoxy polymer matrix composite material. Journal of Advances in Chemistry, 13(4), 6120-6126.
27. Ramamoorthi, R., Jeyakumar.R, \&Ramakrishnan,T. (2017). Effect of Nanoparticles on the Improvement of Mechanical Properties of Epoxy Based Fiber - Reinforced Composites - A Review. International Journal for Science and Advance Research in Technology, 3(11), 1251- 1256.

28. Ramakrishnan, T., Sampath, P. S., \&Ramamoorthi, R. (2016). Investigation of Mechanical Properties and Morphological Study of the Alkali Treated Agave Angustifolia MarginataFiber Reinforced Epoxy Polymer Composites. Asian Journal of Research in Social Sciences and Humanities, 6(9), 461-472.

29. Ramakrishnan, T \& Sampath, P.S. (2016). Thermogravimetric Analysis (TGA) and the Effect of Moisture Absorption on the Mechanical Properties of New Agave Angustifolia Marginata 3 Fiber (AAMF) Reinforced Epoxy Polymer Composite Material, International Journal of Printing, Packaging \& Allied Sciences, 4(5), 32453256.

30. Ramakrishnan, T., Sathish, K., Sampath, P. S., \&Anandkumar, S. (2016). Experimental investigation and optimization of surface roughness of AISI 52100 alloy steel material by using Taguchi method. Advances in Natural and Applied Sciences, 10(6 SE), 130-138.

31. Sathish, K., Ramakrishnan, T., \&Sathishkumar, S. (2016). Optimization of turning parameters to improve surface finish of $16 \mathrm{Mn}$ Cr 5 material. Advances in Natural and Applied Sciences, 10(6 SE), 151-157.

32. S. Karthik Raja S.Balasubramani, S.Venkatesh, T.Ramakrishnan (2015). Effect Of Cryogenic Tempering On Steel, International Journal of Mechanical and Civil Engineering, 2 (6), 98-113.

33. Venkatesh, S., \&Sakthivel, M. (2017). 'Numerical Investigation and Optimization for Performance Analysis in Venturi Inlet Cyclone Separator', Desalination and Water treatment, Vol. 90, No. 9, pp. 168179.

34. Venkatesh, S., Sakthivel, M., Sudhagar, S.,\&Ajith Arul Daniel, S.(2018). 'Modification of the cyclone separator geometry for improving the performance using Taguchi and CFD approach', Particulate Science and Technology, Doi:10.1080/02726351.2018.1458354.

35. Venkatesh, S., Bruno Clement, I., Avinasilingam, M., \&Arulkumar, E. 


\section{International Journal of Engineering Applied Sciences and Technology, 2019 \\ Vol. 4, Issue 2, ISSN No. 2455-2143, Pages 135-140 \\ Published Online June 2019 in IJEAST (http://www.ijeast.com)}

(2017). "Design of Experiment Technique for Improving the Performance of Stirling Engine", International Research Journal of Engineering and Technology, Vol. 4, No. 5, pp. 62-65.

36. Venkatesh, S., Balasubramani, S., Venkatramanan, S., \&Gokulraj, L. "Standardization of hpx spool for lead time reduction of string test", Journal of Mechanical and Civil Engineering,Vol. 2, No. 6, pp. 62-79.

37. Kousalya Devi, S., Venkatesh, S., \&Chandrasekaran. P. (2015). "Performance Improvementof Venturi Wet Scrubber,'Journal of Mechanical and Civil Engineering, Vol. 2, No. 4, pp. 1-9.

38. Arunkumar, P., Dhachinamoorthi, P., Saravanakumar, K., \&Venkatesh, S. (2014)."Analysis and Investigation of Centrifugal Pump Impellers Using CFD," Engineering Science and Technology: An International Journal, Vol. 4, No. 4, pp. 112-117.

39. Venkatesh, S., \&Sakthivel, M. (2017). 'Numerical Investigation and Optimization for Performance Analysis in Venturi Inlet Cyclone Separator', Desalination and Water treatment, Vol. 90, No. 9, pp. 168179.

40. Venkatesh, S., Sakthivel, M., Sudhagar, S.,\&Ajith Arul Daniel, S.(2018).
'Modification of the cyclone separator geometry for improving the performance using Taguchi and CFD approach', Particulate Science and Technology, Doi:10.1080/02726351.2018.1458354.

41. Venkatesh, S., Bruno Clement, I., Avinasilingam, M., \&Arulkumar, E. (2017). "Design of Experiment Technique for Improving the Performance of Stirling Engine", International Research Journal of Engineering and Technology,Vol. 4, No. 5, pp. 62-65

42. Venkatesh, S., Balasubramani, S., Venkatramanan, S., \&Gokulraj, L. "Standardization of hpx spool for lead time reduction of string test", Journal of Mechanical and Civil Engineering,Vol. 2, No. 6, pp. 62-79.

43. Kousalya Devi, S., Venkatesh, S., \&Chandrasekaran. P. (2015). "Performance Improvement of Venturi Wet Scrubber,'Journal of Mechanical and Civil Engineering, Vol. 2, No. 4, pp. 1-9.

44. Arunkumar, P., Dhachinamoorthi, P., Saravanakumar, K., \&Venkatesh, S. (2014)."Analysis and Investigation of Centrifugal Pump Impellers Using CFD," Engineering Science and Technology: An International Journal, Vol. 4, No. 4, pp. 112-117. 